\title{
Evaluation of cytotoxic and chemotherapeutic properties of boldine in breast cancer using in vitro and in vivo models
}

This article was published in the following Dove Press journal:

Drug Design, Development and Therapy

6 June 2014

Number of times this article has been viewed

\author{
Mohammadjavad Paydar' \\ Behnam Kamalidehghan ${ }^{2}$ \\ Yi Li Wong' \\ Won Fen Wong ${ }^{3}$ \\ Chung Yeng Looi' \\ Mohd Rais Mustafa' \\ 'Department of Pharmacology, \\ ${ }^{2}$ Department of Pharmacy, \\ ${ }^{3}$ Department of Medical Microbiology, \\ Faculty of Medicine, University of \\ Malaya, Kuala Lumpur, Malaysia
}

\begin{abstract}
To date, plants have been the major source of anticancer drugs. Boldine is a natural alkaloid commonly found in the leaves and bark of Peumus boldus. In this study, we found that boldine potently inhibited the viability of the human invasive breast cancer cell lines, MDAMB-231 (48-hour $\mathrm{IC}_{50} 46.5 \pm 3.1 \mu \mathrm{g} / \mathrm{mL}$ ) and MDA-MB-468 (48-hour $\mathrm{IC}_{50} 50.8 \pm 2.7 \mu \mathrm{g} / \mathrm{mL}$ ). Boldine had a cytotoxic effect and induced apoptosis in breast cancer cells as indicated by a higher amount of lactate dehydrogenase released, membrane permeability, and DNA fragmentation. In addition, we demonstrated that boldine induced cell cycle arrest at G2/M phase. The anticancer mechanism is associated with disruption of the mitochondrial membrane potential and release of cytochrome $\mathrm{c}$ in MDA-MB-231. Boldine selectively induced activation of caspase-9 and caspase-3/7, but not caspase- 8 . We also found that boldine could inhibit nuclear factor kappa $\mathrm{B}$ activation, a key molecule in tumor progression and metastasis. In addition, protein array and Western blotting analysis showed that treatment with boldine resulted in downregulation of Bcl-2 and heat shock protein 70 and upregulation of Bax in the MDA-MB-231 cell line. An acute toxicity study in rats revealed that boldine at a dose of $100 \mathrm{mg} / \mathrm{kg}$ body weight was well tolerated. Moreover, intraperitoneal injection of boldine ( 50 or $100 \mathrm{mg} / \mathrm{kg}$ ) significantly reduced tumor size in an animal model of breast cancer. Our results suggest that boldine is a potentially useful agent for the treatment of breast cancer.
\end{abstract}

Keywords: boldine, breast cancer, caspase cascade, Bcl-2/Bax, heat shock protein 70, nuclear factor kappa B

\section{Introduction}

Cancer is a major health problem of global concern and afflicts a substantial portion of people all around the world. ${ }^{1}$ Breast cancer is a complex and heterogeneous disease, which has become the leading diagnosed cancer in women worldwide and also one of the most frequent causes of cancer death in women, especially in western populations and industrialized countries. ${ }^{2}$ So far, over 1.3 million cases of invasive breast cancer have been reported worldwide, and statistical reviews reveal a total death rate of up to 450,000 cases annually in women. ${ }^{3}$

Although the mainstay of treatment for breast cancer has been surgical removal of the tumor, treatment regimens have evolved from the use of adjuvant chemotherapeutic drugs to hormone therapy. ${ }^{4,5}$ Despite the marked improvement in the therapeutic armamentarium available for breast cancer in recent decades, there is still a considerable death rate among women in the USA ( $15 \%$ of all cancer deaths) and other parts of the world. ${ }^{6}$ Among the reasons for this predicament are the emergence of drug resistance and the severe side effects of chemotherapy, which are major unresolved issues in
Correspondence: Chung Yeng Looi Department of Pharmacology, Faculty of Medicine, University of Malaya, Kuala Lumpur 50603, Malaysia

Tel +603 79675722

Fax +60379675726

Email looicy@um.edu.my 
clinical oncology. Therefore, the search continues for novel anticancer compounds with improved features.

Carcinogenesis is a multistage process in which unregulated cell proliferation as well as resistance to apoptosis are the initial key steps responsible for its progression. ${ }^{7}$ Programmed cell death, commonly known as apoptosis, is one of the first-line defenses in multicellular organisms to stop tumor development. Apoptosis is characterized by distinct morphological changes, including cell shrinkage, chromatin condensation, membrane permeability, and disruption of the mitochondrial membrane. ${ }^{8,9}$ Organismal homeostasis depends on an intricate coordination between cell death and cell proliferation. Factors (genetic or environmental) that upset this balance could lead to cancer development and uncontrolled cell growth. ${ }^{10-12}$ In recent years, drugs targeting apoptotic pathways have been explored for cancer therapy as well as chemoprevention. In fact, anticancer drugs such as camptothecin, paclitaxel, and doxorubicin exert their effect by regulating key events or molecules in apoptosis-inducing signal transduction pathways. ${ }^{13}$

Plant-derived compounds play a substantial role in modern medicine, and their therapeutic properties have been investigated intensively in the laboratory as well as in clinical trials in recent decades. This trend is spurred by increasing public awareness and research findings regarding the severe side effects of chemically synthesized drugs, which have led to the search for novel anticancer drugs derived from natural products. Boldine [(S)-2,9-dihydroxy-1, 10-dimethoxyaporphine; Figure 1A] is an aporphine alkaloid abundantly found in Peumus boldus Molina, a native tree in Chile known as the "boldo". ${ }^{14}$ In general, boldine is well known for its potent antioxidant activity. However, recent studies have found that this compound also possesses antitrypanosomal, ${ }^{15}$ hepatoprotective, ${ }^{16}$ and anti-inflammatory properties. ${ }^{17}$ Although a preliminary cytotoxic effect was reported in bladder carcinoma and glioma cancer cells, ${ }^{18,19}$ the anticancer mechanism of boldine has yet to be demonstrated. In the present study, we investigated the antitumor activity of boldine in breast adenocarcinoma using in vitro and in vivo models.

\section{Materials and methods}

\section{Materials}

Boldine (>98\%), insulin, HEPES, and epidermal growth factor were purchased from Sigma-Aldrich (St Louis, MO, USA). Cell culture medium, fetal bovine serum, penicillin, and streptomycin were obtained from Gibco (Invitrogen, Life Technologies, Inc., Rockville, MD, USA). Z-VAD-FMK, a pan caspase inhibitor, was sourced from R\&D Systems (Minneapolis, MN, USA).

\section{Cell culture}

Two human breast cancer cell lines (MDA-MB-231 and MDAMB-468) and a rat mammary tumor cell line (LA7) were purchased from the American Type Culture Collection (ATCC, Manassas, VA, USA). MDA-MB-231 and MDA-MB-468 cells were grown in Dulbecco's Modified Eagle's Medium (Gibco BRL, Carlsbad, CA, USA) supplemented with 10\% heatinactivated fetal bovine serum, and $1 \%$ penicillin and streptomycin. LA7 cells were maintained in Dulbecco's Modified Eagle's Medium supplemented with 5\% fetal bovine serum, $1 \%$ penicillin and streptomycin, $4.5 \mathrm{~g} / \mathrm{L}$ glucose, $0.005 \mathrm{mg} / \mathrm{mL}$ insulin, and $20 \mathrm{mM}$ HEPES. Cells were cultured in tissue culture flasks (Corning, New York, NY, USA) and kept in an incubator at $37^{\circ} \mathrm{C}$ in a humidified atmosphere with $5 \% \mathrm{CO}_{2}$. For experimental purposes, cells in the exponential growth phase (approximately $70 \%-80 \%$ confluence) were used.

\section{MTT cell viability assay}

The cytotoxic effect of boldine was assessed using the 3-[4,5-dimethylthiazol-2-yl]-2,5 diphenyltetrazolium bromide (MTT) cell viability assay. ${ }^{20}$ The assay was performed for different treatment time points. Briefly, $8.0 \times 10^{3}$ cells were seeded in a $96-w e l l$ plate and incubated overnight at $37^{\circ} \mathrm{C}$ in $5 \% \mathrm{CO}_{2}$. On the following day, the cells were treated with a two-fold dilution of six concentrations of boldine, and incubated further at $37^{\circ} \mathrm{C}$ in $5 \% \mathrm{CO}_{2}$ for 24 and 48 hours. The MTT solution was added at $2 \mathrm{mg} / \mathrm{mL}$ for 2 hours before addition of dimethylsulfoxide to dissolve the formazan crystals. The plates were then read in a Chameleon multitechnology microplate reader (Hidex, Turku, Finland) at $570 \mathrm{~nm}$ absorbance. The cell viability percentage after exposure to boldine at the indicated time points was calculated using a previously described method. ${ }^{21}$ The ratio of the absorbance of treated cells to the absorbance of dimethylsulfoxide-treated control cells was determined as a percentage of cell viability. $\mathrm{The}^{\mathrm{IC}} \mathrm{C}_{50}$ value was defined as the concentration of boldine required to reduce the absorbance of treated cells to $50 \%$ of the dimethylsulfoxide-treated control cells. The experiment was carried out in triplicate.

\section{Lactate dehydrogenase release assay}

The cytotoxicity of boldine was determined by measuring the release of lactate dehydrogenase. MDA-MB-231 cells were pretreated with different concentrations of boldine for 48 hours and the supernatant of the treated and untreated cells was used to assess lactate dehydrogenase activity. First, $100 \mu \mathrm{L}$ of lactate 
<smiles>COc1cc2c(cc1O)CC1NCCc3cc(OC)c(O)c-2c31</smiles>
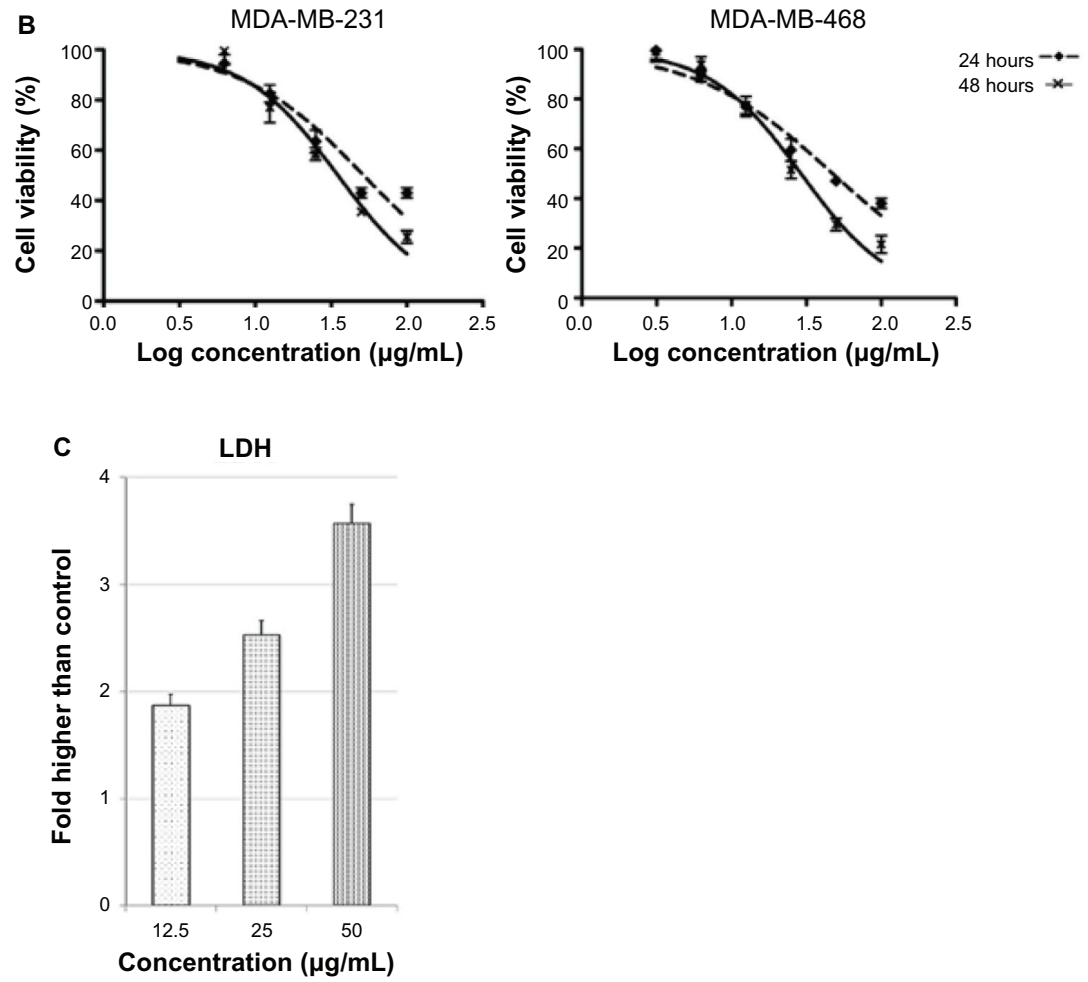

Figure I Structure of boldine and its effect on breast cancer cell viability. (A) Chemical structure of boldine. (B) Growth curve of boldine-treated MDA-MB-23I and MDA-MB-468 cells at 24 and 48 hours. (C) LDH release assay revealed significant cytotoxicity of boldine on MDA-MB-23I cells.

Abbreviation: $\mathrm{LDH}$, lactate dehydrogenase.

dehydrogenase reaction solution was added to each well, the plate was incubated at room temperature for 30 minutes, and the absorbance was then read at $490 \mathrm{~nm}$ using an Infinite ${ }^{\circledR} 200$ Pro (Tecan, Männedorf, Switzerland) microplate reader. The intensity of the red color formed in treated and untreated samples is proportional to lactate dehydrogenase activity and the number of damaged cells.

\section{Acridine orange/propidium iodide double staining}

Cells seeded in $25 \mathrm{~cm}^{2}$ culture flasks $\left(1.0 \times 10^{6}\right.$ cells/flask $)$ were treated with dimethylsulfoxide or boldine at the $\mathrm{IC}_{50}$ dose and incubated at $37^{\circ} \mathrm{C}$ in $5 \% \mathrm{CO}_{2}$ for different time periods
(24, 48, and 72 hours). The staining solution was prepared by adding $100 \mu \mathrm{L}$ of $1 \mathrm{mg} / \mathrm{mL}$ propidium iodide (Sigma-Aldrich Company Ltd, Gillingham, UK) and $100 \mu \mathrm{L}$ of $1 \mathrm{mg} / \mathrm{mL}$ acridine orange (Sigma-Aldrich Company Ltd) to $10 \mathrm{~mL}$ of phosphate-buffered saline. The cell suspensions were mixed $1: 1$ with the staining solution in microtiter wells, incubated for 20 minutes, and observed under a BX51 ultravioletfluorescent microscope (Olympus, Tokyo, Japan).

\section{Flow cytometry-based apoptosis and cell cycle analysis}

Cells seeded in $25 \mathrm{~cm}^{2}$ culture flasks $\left(2.0 \times 10^{5}\right.$ cells/flask $)$ were treated with dimethylsulfoxide or boldine at the 
indicated dosages and incubated at $37^{\circ} \mathrm{C}$ in $5 \% \mathrm{CO}_{2}$ for 24 hours. Cells were then collected and stained with Annexin $\mathrm{V}$ and propidium iodide as described previously. ${ }^{21}$ Stained cells were analyzed using a Canto II flow cytometer (BD Biosciences, San Jose, CA, USA) to determine apoptotic or necrotic cells. For cell cycle analysis, control or boldinetreated cells were fixed and stained with propidium iodide supplemented with RNase (BD Biosciences) before analysis by flow cytometer.

\section{Multiparameter cytotoxicity assay}

A Cellomics multiparameter cytotoxicity 3 kit (Thermo Fisher Scientific, Waltham, MA, USA) was used as described in detail previously. ${ }^{22}$ This kit enables simultaneous measurement of mitochondrial membrane potential (MMP) change, cytochrome c release, and cell membrane permeability. Briefly, $1 \times 10^{4}$ MDA-MB-231 cells per well were seeded in a 96 -well plate and incubated overnight at $37^{\circ} \mathrm{C}$ in $5 \% \mathrm{CO}_{2}$. Cells were treated with different concentrations of boldine or dimethylsulfoxide (negative control) for 24 hours. Next, MMP dye and cell permeability dye were added to live cells and incubated for 30 minutes at $37^{\circ} \mathrm{C}$. Cells were fixed, permeabilized, and blocked with $1 \times$ blocking buffer before probing with primary cytochrome c primary antibody and secondary DyLight 649 conjugated goat antimouse immunoglobulin $\mathrm{G}$ for one hour each. Hoechst 33342 was added into the staining solution to stain the nucleus. Plates with stained cells were analyzed using the ArrayScan high content screening system (Thermo Fisher Scientific). The ArrayScan high content screening system is a computerized automated fluorescence imaging microscope that automatically identifies stained cells and reports the intensity and distribution of fluorescence in individual cells. In each well, 1,000 cells were analyzed. Images were acquired for each fluorescence channel, using suitable filters. Images and data regarding intensity and texture of the fluorescence within each cell, as well as the average fluorescence of the cell population within the well, were stored in a Microsoft SQL database for easy retrieval. Data were captured, extracted, and analyzed with ArrayScan II Data Acquisition and Data Viewer version 3.0 software (Thermo Fisher Scientific).

\section{DNA preparation}

For deoxyribonucleic acid (DNA) preparation, treated and untreated cells were trypsinized and pelleted in a $15 \mathrm{~mL}$ tube by centrifugation at 1,000 rpm for 2 minutes. DNA extraction was carried out using a DNeasy Blood and Tissue kit (Qiagen, Hilden, Germany). In brief, $200 \mu \mathrm{L}$ of lysis buffer (Buffer AL) was added to the cell pellet followed by 10 minutes of incubation at $56^{\circ} \mathrm{C}$. The lysate was then thoroughly mixed with $200 \mu \mathrm{L}$ of ethanol $(96 \%-100 \%)$, transferred to a DNeasy Mini spin column, placed in a $2 \mathrm{~mL}$ collection tube, and centrifuged at $\geq 8,000 \mathrm{rpm}$ for one minute. The flow-through was discarded and the spin column was washed twice using AW1 and AW2 buffers before eluting the DNA by adding elution buffer (Buffer AE), followed by centrifugation at $\geq 8,000 \mathrm{rpm}$ for one minute.

\section{DNA fragmentation analysis by agarose gel electrophoresis}

First, $30 \mu \mathrm{L}$ samples of the extracted DNA were mixed with $3 \mathrm{~mL}$ of loading buffer. The samples were resolved on $1 \%$ agarose gel and visualized by ultraviolet light after standard ethidium bromide staining.

\section{Bioluminescent assays for caspase-3/7, caspase- 8 , and caspase- 9 activity}

A dose-dependent study of caspase-3/7, caspase-8, and caspase- 9 activity was performed in triplicate using CaspaseGlo $^{\circledR} 3 / 7,8$, and 9 assay kits (Promega, Madison, WI, USA) on a white 96 -well microplate. A total of $1 \times 10^{4}$ MDA-MB-231 cells were seeded per well and incubated with different concentrations of boldine $(12.5,25$, and $50 \mu \mathrm{g} / \mathrm{mL})$ or $50 \mu \mathrm{g} / \mathrm{mL}$ boldine $+20 \mu \mathrm{M}$ pan caspase inhibitor, Z-VAD-FMK, for 24 hours. Caspase activity was investigated according to the manufacturer's protocol. Briefly, $100 \mu \mathrm{L}$ of caspase-Glo reagent was added and incubated at room temperature for 30 minutes. The presence of active caspases from apoptotic cells cleave the aminoluciferin-labeled synthetic tetrapeptide, thus releasing substrate for the luciferase enzyme. The caspase activity was measured using an Infinite ${ }^{\circledR} 200$ Pro microplate reader (Tecan, Männedorf, Switzerland).

\section{Nuclear factor kappa B translocation}

Briefly, $1.0 \times 10^{4} \mathrm{MDA}-\mathrm{MB}-231$ cells were seeded in a 96-well plate and incubated overnight at $37^{\circ} \mathrm{C}$ in $5 \% \mathrm{CO}_{2}$. The cells were pretreated with different concentrations of boldine for 3 hours and then stimulated with $1 \mathrm{ng} / \mathrm{mL}$ tumor necrosis factor alpha (TNF- $\alpha$ ) for 30 minutes. The medium was removed and the cells were fixed and stained with nuclear factor kappa B

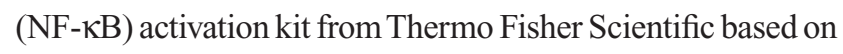
the manufacturer's instructions. The plate was evaluated on an ArrayScan high content screening reader. Calculation of the cytoplasmic and nuclear NF- $\kappa \mathrm{B}$ intensity ratio was carried out using Cytoplasm to Nucleus Translocation BioApplication software (Thermo Fisher Scientific). The average intensity 
of 200 objects (cells) per well was quantified. The ratios were then compared between TNF- $\alpha$-stimulated, treated, and untreated cells. $^{22}$

\section{Human apoptosis proteome profiler array}

To determine the probable pathway of apoptosis induction mediated by boldine in MDA-MB-231 cells, detection of several apoptosis-related markers was done using the Proteome Profiler Array (RayBio ${ }^{\circledR}$ Human Apoptosis Antibody Array kit; RayBiotech, Inc., Norcross, GA, USA) according to the manufacturer's instructions. Briefly, cells were treated with an $\mathrm{IC}_{50}$ dose of boldine. Untreated cells were used as the negative control. First, $300 \mu \mathrm{g}$ proteins from each sample were incubated with the human apoptosis array overnight. The apoptosis array data were then quantified by scanning the membrane on a Biospectrum AC ChemiHR 40 (UVP Inc., Upland, CA, USA), and analysis of the array was performed using image analysis software according to the manufacturer's instructions.

\section{Western blotting}

Western blotting was used to investigate the expression of apoptosis-related proteins, including $\mathrm{Bax}, \mathrm{Bcl}-2$, and heat shock protein (HSP)70. MDA-MB-231 cells were treated with boldine in a concentration-dependent manner for 24 hours. Untreated cells served as the negative control. The total protein content in the cells was extracted with cell lysis buffer ( 50 $\mathrm{mM}$ Tris- $\mathrm{HCl} \mathrm{pH}$ 8.0, $120 \mathrm{mM} \mathrm{NaCl}, 0.5 \%$ NP-40, $1 \mathrm{mM}$ phenylmethylsulfonyl fluoride); $40 \mu \mathrm{g}$ of protein extract was separated by $10 \%$ sodium dodecyl sulfate polyacrylamide gel electrophoresis and then transferred to a polyvinylidene difluoride membrane (Bio-Rad, Hercules, CA, USA) using a semidry transfer unit (TE 70X, Hoefer Inc., Holliston, MA, USA) blocked with 5\% nonfat milk in TBS-Tween buffer (0.12 M Tris-base, $1.5 \mathrm{M} \mathrm{NaCl}, 0.1 \%$ Tween 20 ) for one hour at room temperature, and incubated overnight at $4{ }^{\circ} \mathrm{C}$ with the appropriate primary antibodies, ie, $\beta$-actin $(1: 5,000), \mathrm{Bcl} 2$ $(1: 1,000), \operatorname{Bax}(1: 1,000)$, and HSP70 $(1: 1,000)$ purchased from Santa Cruz Biotechnology Inc (Santa Cruz, CA, USA), followed by incubation with alkaline phosphatase-conjugated goat anti-mouse and goat anti-rabbit secondary antibodies (i-DNA, Promega, Madison, USA) for 30 minutes at room temperature, and washing in Tris-buffered saline with Tween 20 for 10 minutes three times on an orbital shaker. The blots were then developed using BCIP ${ }^{\circledR} / \mathrm{NBT}$ solution (Santa Cruz Biotechnology Inc.) for a period of 5-30 minutes to detect the target protein band as a precipitated dark-blue color.

\section{Acute toxicity study}

Healthy Sprague-Dawley rats (15 males and 15 females, aged 8 weeks, weight $165-190 \mathrm{~g}$ ) were obtained from the Animal House, Faculty of Medicine, University of Malaya, Kuala Lumpur. The rats were fed with standard rat pellets and tap water ad libitum. The acute toxicity of boldine was evaluated to determine a safe dosage. The animals were randomly assigned into three groups (five males and five females per group), labeled as: vehicle (treated with $50 \%$ ethanol/ water); low dose (treated with $50 \mathrm{mg} / \mathrm{kg} /$ day of boldine dissolved in 50\% ethanol/water); and high dose (treated with $100 \mathrm{mg} / \mathrm{kg} /$ day of boldine dissolved in $50 \%$ ethanol/water). Boldine and vehicle were administered intraperitoneally to the animals for 14 days. Mortality or any onset of clinical or toxicological symptoms was recorded throughout the study period. On day 15 , blood was drawn from the animals for hematology and serum biochemistry investigations according to the methods recommended by Organization for Economic Cooperation and Development (OECD).

\section{Mammary tumor implantation}

Rat LA7 mammary adenocarcinoma cells at around $75 \%-85 \%$ confluence were trypsinized, washed once in Dulbecco's Modified Eagle's Medium (supplemented with 5\% fetal bovine serum), spun down, and suspended in the same medium. A total of one million cells in a volume of $100 \mu \mathrm{L}$ were injected into the mammary fat pads of 20 female Sprague-Dawley rats.

\section{Treatment of implanted animals}

Ten days after implantation of LA7 mammary carcinoma, the animals were randomly separated into four groups $(n=5$ per group): control (untreated); vehicle (treated with 50\% ethanol/ water); low dose (treated with $50 \mathrm{mg} / \mathrm{kg} /$ day of boldine dissolved in $50 \%$ ethanol/water); and high dose (treated with $100 \mathrm{mg} / \mathrm{kg}$ /day of boldine dissolved in 50\% ethanol/water). Boldine and vehicle were administered intraperitoneally to the animals for 14 consecutive days. At the end of treatment, the rats were euthanized and the entire tumor was removed, sectioned, and fixed in 10\% paraformaldehyde.

\section{Evaluation of effect of boldine on tumor size}

The total tumor volume $\left(\mathrm{mm}^{3}\right)$ was quantified by multiplication of the slice sections and by summing the segmented areas.

\section{Statistical analysis}

Experimental values are presented as the mean \pm standard deviation. Analysis of variance or the Student's $t$-test was 
performed using GraphPad Prism 5 software (GraphPad Software Inc., La Jolla, CA, USA). Statistical significance was defined when $P<0.05$.

\section{Results}

\section{Boldine reduces breast cancer} cell viability

The effect of boldine on cell viability was evaluated in MDAMB-231 and MDA-MB-468 human breast cancer cell lines using the MTT assay. A dose-dependent reduction of cell viability at 24 and 48 hours post-treatment was observed in both breast cancer cell-lines (Figure 1B). At 24 hours, the $\mathrm{IC}_{50}$ values for MDA-MD-231 and MDA-MD-468 were 70.8 \pm 3.5 $\mu \mathrm{g} / \mathrm{mL}$ and $75.7 \pm 4.3 \mu \mathrm{g} / \mathrm{mL}$, respectively. At 48 hours, the $\mathrm{IC}_{50}$ values for MDA-MD-231 and MDA-MD-468 were $46.5 \pm 3.1 \mu \mathrm{g} / \mathrm{mL}$ and $50.8 \pm 2.7 \mu \mathrm{g} / \mathrm{mL}$, respectively.

\section{Boldine induces apoptosis in MDA-MB-23I}

To examine whether the cell viability reduction was due to a cytotoxic effect of boldine, we measured lactate dehydrogenase release from MDA-MB-231 cells treated with different concentrations of boldine for 48 hours. As shown in Figure $1 \mathrm{C}$, boldine dose-dependently increased the released lactate dehydrogenase compared with control cells, indicating cellular toxicity.

To determine whether cell death was mediated by apoptosis, acridine orange (green)/propidium iodide (red)-stained MDA-MB-231 cells were observed under a fluorescent microscope at different time points (24, 48, and 72 hours). Green, round, intact nuclear structures were visible in the control group (Figure 2A). As shown in Figure 2B and C, boldine induced membrane blebbing and nuclear chromatin condensation after 24 and 48 hours of treatment, indicating early apoptosis. Presence of reddish-orange colored (propidium iodide-positive) cells were detected in samples treated for 48 and 72 hours, suggesting late stage of apoptosis (Figure 2D). The results demonstrated features of apoptosis induced by boldine in a time-dependent manner in MDA-MB-231 human breast adenocarcinoma cells.

To verify this further, we examined apoptosis using Annexin $\mathrm{V}$ and propidium iodide staining followed by flow cytometry (Figure 3A). We observed an increase in the
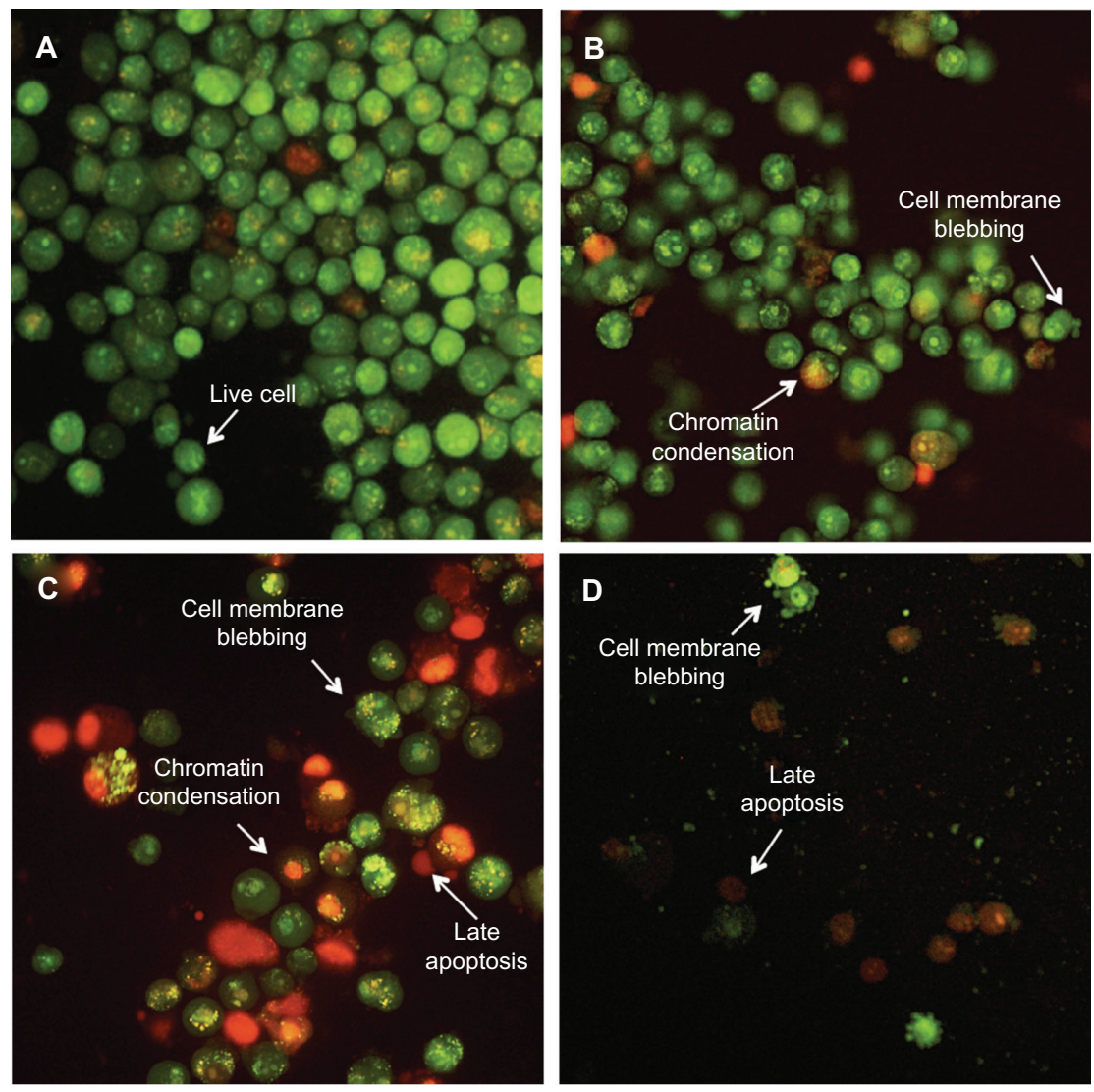

Figure 2 Boldine induces apoptosis in MDA-MB-23I cancer cells. (A) Untreated MDA-MB-23I cells demonstrated normal cellular structure. Early apoptosis features, including membrane blebbing and chromatin condensation, were observed after (B) 24 and (C) 48 hours of treatment with boldine. (D) Late apoptosis and necrosis were noticed after 72 hours of treatment with boldine (magnification, 200×). 
amount of early apoptotic (Annexin V-positive, propidium iodide-negative) cells from $2 \%$ in untreated cells to $5.9 \%$, $16 \%$, and $27 \%$ in response to higher concentration of boldine. In addition, the late-stage apoptotic (Annexin V-positive, propidium iodide-negative) cell population also showed a marked increase from $2.9 \%$ in control cells to $3.1 \%, 8.6 \%$, and $13 \%$ in cells treated with the increasing dosages of boldine.

A

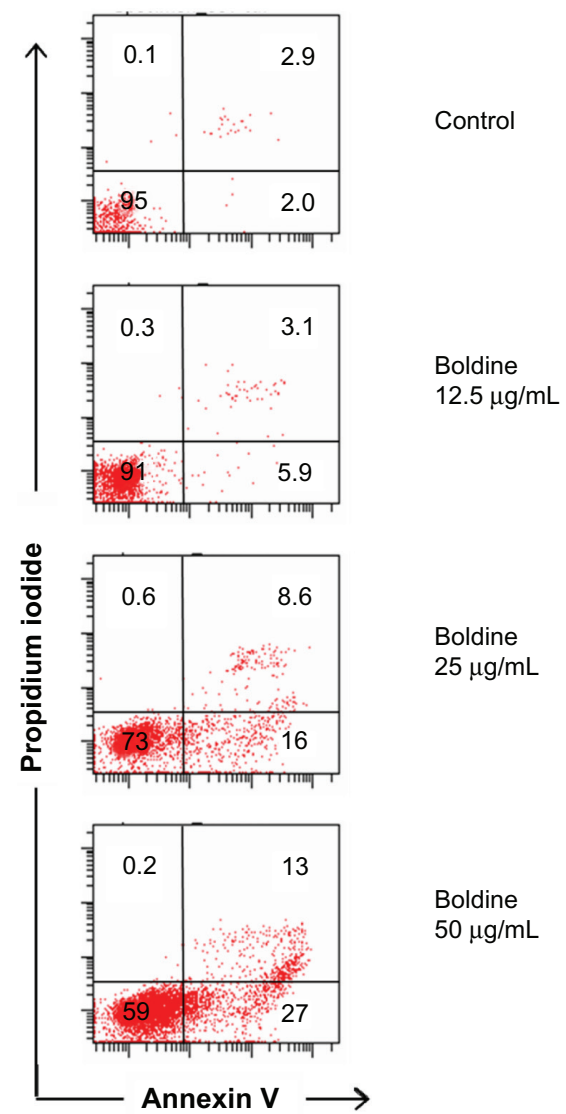

B

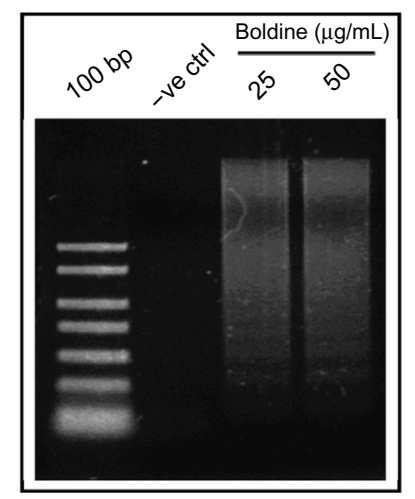

Figure 3 Flow cytometry and DNA ladder analysis of boldine-treated MDA-MB-23। cancer cells. (A) Apoptosis assay by flow cytometry analysis. MDA-MB-23I cells treated with different concentrations of boldine were collected and stained with Annexin $\mathrm{V}$ and propidium iodide followed by flow cytometry analysis. Numbers shown are percentages of cells in each quadrant. (B) Electrophoresis separation of isolated total DNA from control and boldine-treated MDA-MB-23I cells after 24 hours.

Abbreviation: DNA, deoxyribonucleic acid; 100 bp, DNA ladder marker; -ve ctrl, negative control.
We further isolated DNA from control and boldinetreated MDA-MB-231 cells and subjected them to agarose gel electrophoresis. As shown in Figure 3B, DNA laddering was detected in the samples treated with 25 and $50 \mu \mathrm{g} / \mathrm{mL}$ of boldine compared with control, indicating that boldine may induce apoptosis via DNA damage.

\section{Boldine induces cell cycle arrest at $G_{2} / M$ phase}

Next, we examined the cell cycle distribution of MDA-MB231 cells treated with different concentrations of boldine. Cells were fixed and stained with propidium iodide, and the cell cycle distribution was determined by flow cytometry. Our results showed that treatment with boldine induced cell cycle arrest at G2/M phase (Figure 4). The percentage of cell population in $\mathrm{G} 2 / \mathrm{M}$ phase was $26.6 \%$ in control cells. Treatment with boldine induced a gradual increase of the percentages to $32.5 \%, 36.3 \%$, and $39.3 \%$ in response to higher dosages of the compound, suggesting dose-dependent arrest of cells at $\mathrm{G} 2 / \mathrm{M}$ phase.

\section{Effect of boldine on nuclear morphology, membrane permeability, MMP, and cytochrome $c$ release}

As the main source of cellular reactive oxygen species and adenosine triphosphate, mitochondria are the key regulators of mechanisms controlling the survival and death of cells. To examine whether boldine has any effect on mitochondrial function, we added an MMP fluorescent probe into the culture medium of the treated and untreated MDA-MB-231 cells. As shown in Figure 5A and B, the control cells were strongly stained with MMP dye, whereas a dose-dependent reduction of MMP fluorescence intensity reflected destruction of MMP in the boldine-treated cells. Moreover, boldine induced a significant increase in cell membrane permeability and cytochrome $\mathrm{c}$ release in treated MDA-MB-231 cells (Figure 5A and B).

\section{Boldine increases caspase- $3 / 7$ and caspase- 9 activity}

Release of an apoptotic signal such as cytochrome c could activate caspases in the cytosol. To check which caspases were involved, we performed bioluminescent assays to measure caspase-3/7, caspase- 8 , and caspase- 9 activity in MDA-MB-231 cells treated with different concentrations of boldine for 24 hours. As shown in Figure 6, a significant dosedependent increase in caspase- $3 / 7$ and caspase- 9 activity was 


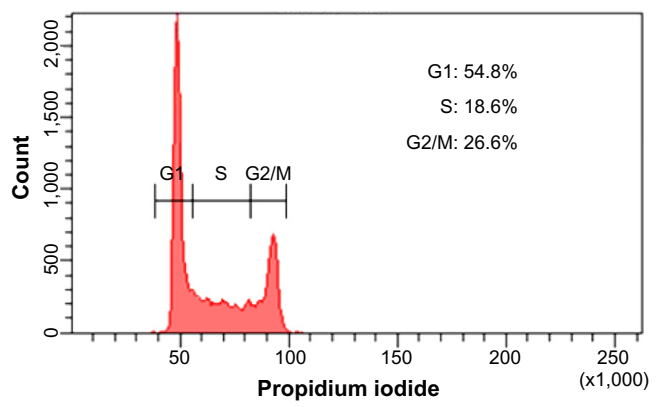

Control

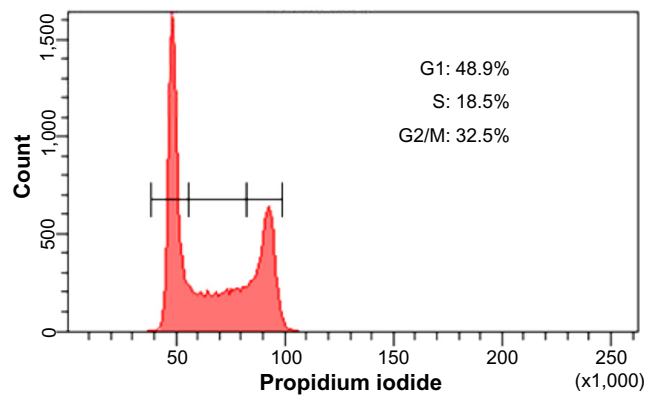

Boldine $12.5 \mu \mathrm{g} / \mathrm{mL}$

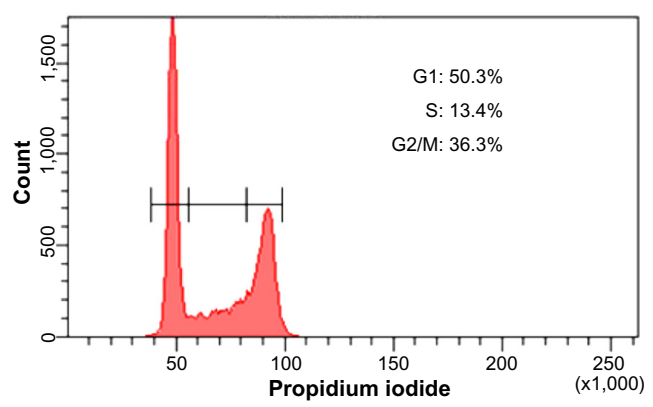

Boldine $25 \mu \mathrm{g} / \mathrm{mL}$

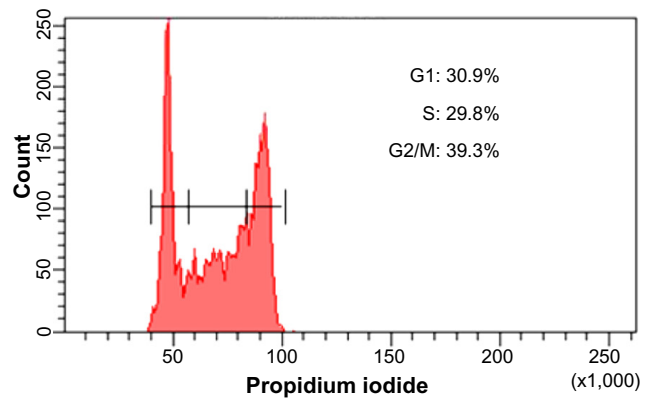

Boldine $50 \mu \mathrm{g} / \mathrm{mL}$

Figure 4 Boldine induces cell cycle arrest at $\mathrm{G} 2 / \mathrm{M}$ stage. After incubation with dimethylsulfoxide or boldine for 24 hours, MDA-MB-23I cells were fixed and stained with propidium iodide, followed by flow cytometry analysis to determine cell cycle distribution. Percentages of cells at GI, S, and G2/M are as indicated.

detected in boldine-treated cells, while no marked change was observed in caspase- 8 activity.

\section{Boldine inhibits TNF- $\alpha$-induced NF- $\kappa B$ nuclear translocation}

$\mathrm{NF}-\mathrm{KB}$ is a transcription factor that is critical for inflammatory responses and progression of cancer. Activation of NF- $\kappa B$ in response to inflammatory cytokines, such as TNF- $\alpha$, mediates nuclear migration to enable DNA binding activity and facilitate target gene expression. In this study, we investigated the effect of boldine on TNF- $\alpha$-mediated NF- $\kappa B$ activation in MDA-MB-231 cells. The cells were pretreated for 3 hours with boldine or curcumin (the positive control) and then stimulated for 30 minutes using $1 \mathrm{ng} / \mathrm{mL}$ TNF- $\alpha$. As shown in Figure 7A, curcumin $50 \mu \mathrm{M}$ promoted accumulation of NF- $\mathrm{\kappa B}$ in the cytoplasm after stimulation by TNF- $\alpha$. In contrast, boldine partially blocked the translocation of NF- $\kappa B$ from cytoplasm to nucleus. The significant decrease in nuclear NF- $\kappa B$ translocation in MDA-MB-231 cells treated with $25 \mu \mathrm{g} / \mathrm{mL}$ and $50 \mu \mathrm{g} / \mathrm{mL}$ boldine confirms the inhibitory activity of boldine against nuclear translocation of NF- $\kappa B$ (Figure 7B).

\section{Effect of boldine on apoptotic markers}

To examine which molecules or pathways are involved in boldine-induced apoptosis, we treated MDA-MB-231 cells with boldine for 24 hours. Cells were lysed and apoptotic markers were screened using protein array assays. As shown in Figure 8, we observed changes in the major markers involved in the apoptosis signaling pathway, such as Bax, Bcl-2, and Bim. Moreover, HSP70, a significant chaperone involved in the apoptosis process, was also downregulated in boldine treated-cells.

\section{Boldine upregulates Bax and suppresses expression of $\mathrm{Bcl}-2$ and HSP70 proteins}

Although many proteins may be upregulated or downregulated during apoptosis, we noticed that the Bcl-2 family proteins (Bcl-2 and Bax) and HSP70 expression levels were significantly affected in the protein array. Next, we moved on to confirm the protein array results using Western blot analysis. Exposure of MDA-MB-231 cells to boldine increased expression of the proapoptotic protein Bax and decreased expression of the antiapoptotic Bcl-2 protein and HSP70 in a concentration-dependent manner (Figure 9).

\section{Boldine induces no significant toxicity in vivo}

For the acute toxicity study, Sprague-Dawley rats were treated with boldine at dosages of $50 \mathrm{mg} / \mathrm{kg} /$ day and 100 $\mathrm{mg} / \mathrm{kg} /$ day for 14 days. All animals survived the treatment period. No physical changes was observed in the rats' skin, fur, eyes, mucus membranes, tremors, salivation, behavior patterns, and sleep. A gradual body weight increase was observed in the male and female boldine-treated rats, but the 
A

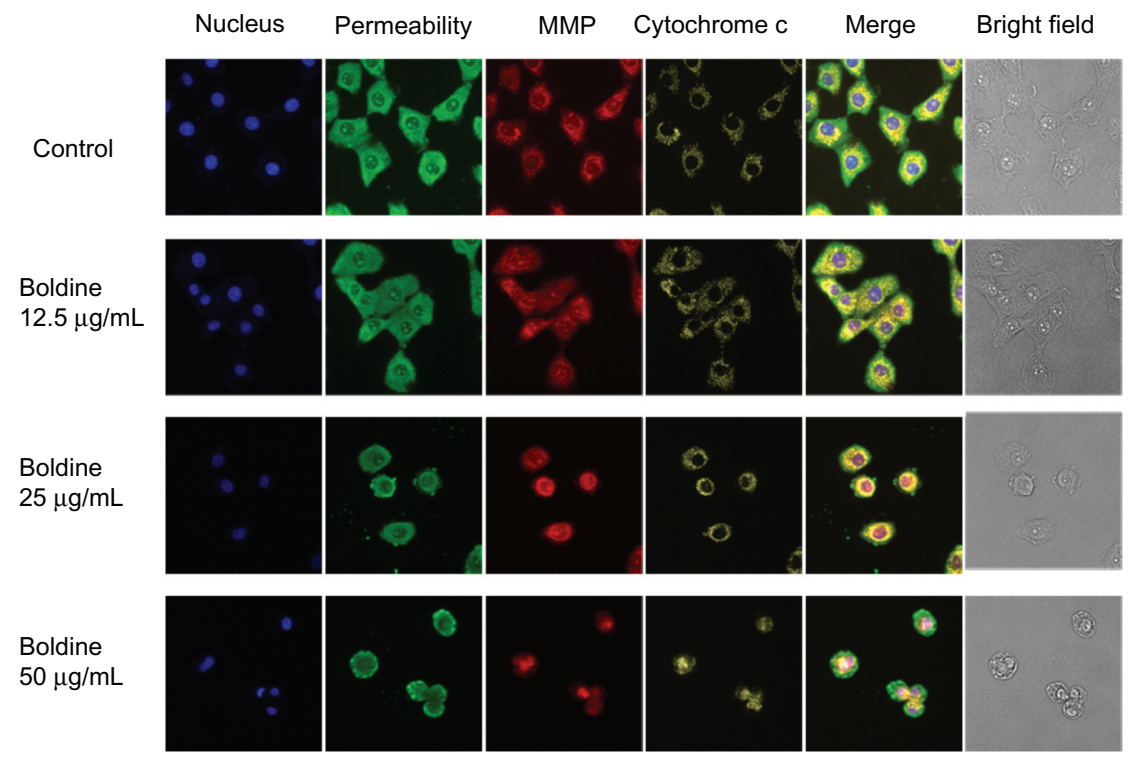

B

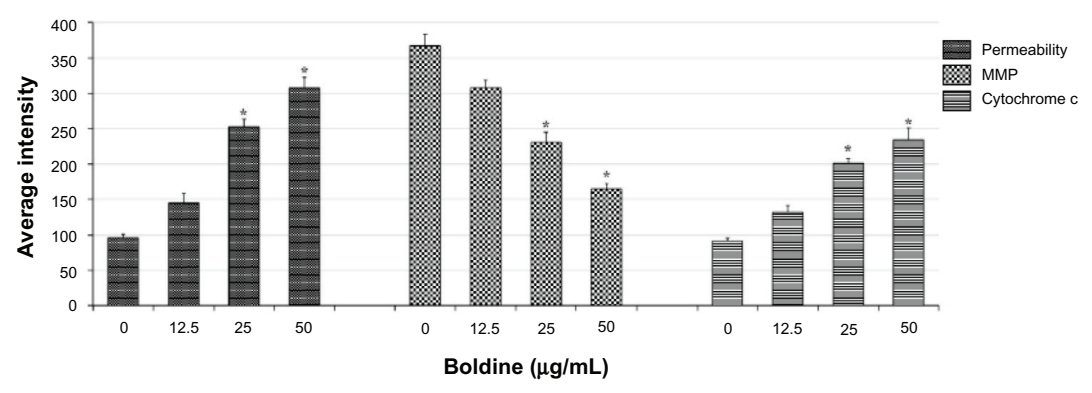

Figure 5 Effect of boldine on cytochrome c, membrane permeability, and MMP. (A) Representative images of boldine-treated and untreated MDA-MB-23I cells, stained with Hoechst 33342 for nuclear, cytochrome c, membrane permeability, MMP dyes. Boldine induced a noteworthy elevation in membrane permeability, cytochrome c release, and marked reduction in MMP (magnification, 200x). (B) Representative bar charts indicating mean fluorescence intensities of cell permeability, MMP, and cytochrome $\mathrm{c}$ release in control and boldine-treated MDA-MB-23I cells. $* P<0.05$ by Student's $t$-test.

Abbreviation: MMP, mitochondrial membrane potential.

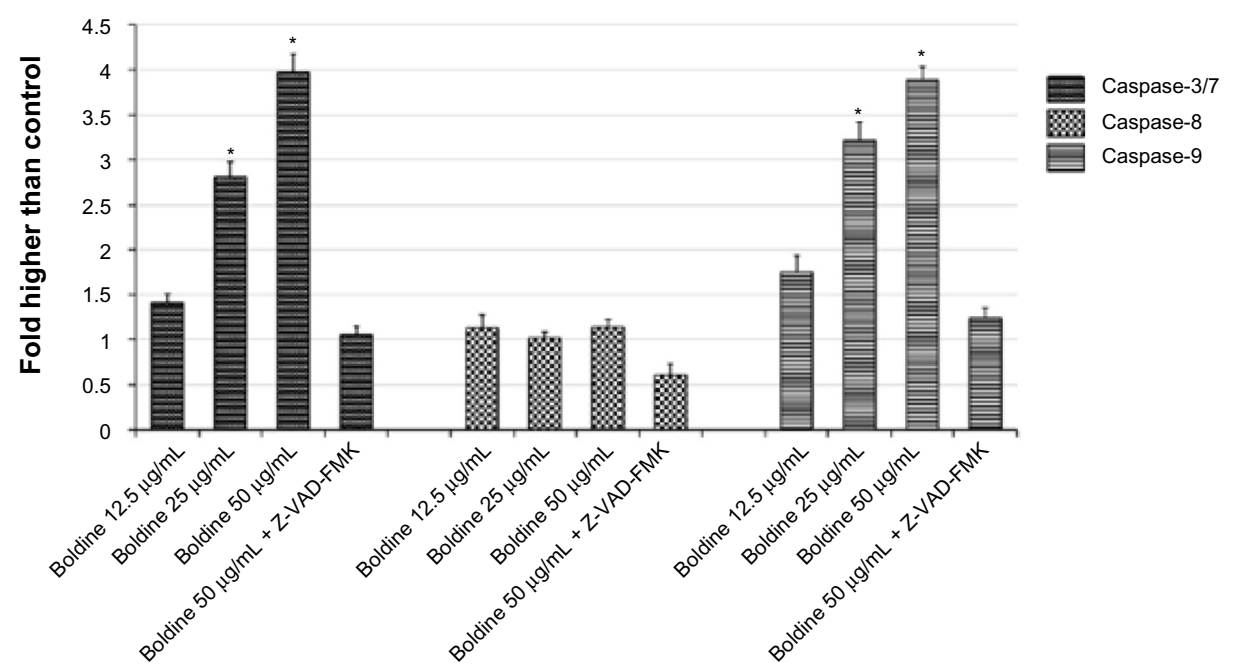

Figure 6 Boldine activates intrinsic caspase-3/7 and caspase-9 activity. Relative luminescence expression of caspase-3/7, caspase-8, and caspase-9 in MDA-MB-23। cells treated with various concentrations of boldine $(12.5,25,50 \mu \mathrm{g} / \mathrm{mL})$ or $50 \mu \mathrm{g} / \mathrm{mL}$ boldine with $20 \mu \mathrm{M} Z$ Z-VAD-FMK, a pan caspase inhibitor. ${ }^{*}<<0.05$ by Student's $t$-test. 
A
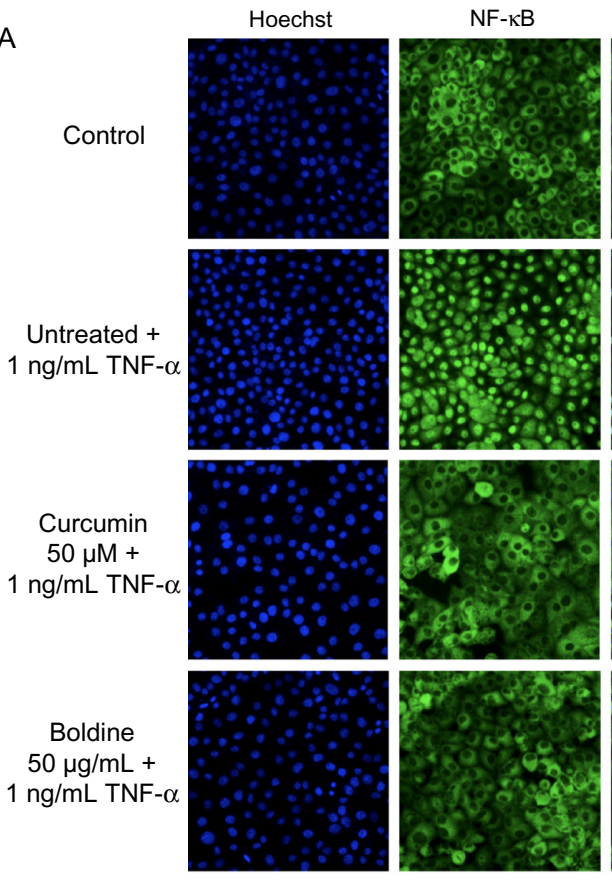

B

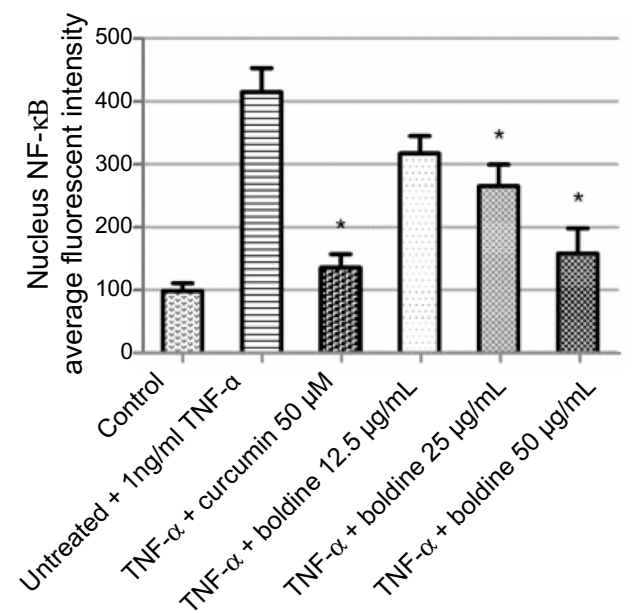

Figure 7 Boldine inhibits TNF- $\alpha$-induced NF- $\kappa B$ nuclear translocation. (A) Photographs of intracellular targets of stained MDA-MB-23I cells, treated with boldine or curcumin (positive control) for 3 hours and then stimulated for 30 minutes with I ng/mL TNF- $\alpha$ (NF- $\mathrm{KB}$ activation). (B) Representative bar chart indicating that treatment with boldine partially blocked NF-KB translocation from the cytoplasm to the nucleus in TNF- $\alpha-$ stimulated MDA-MB-23I cells. Data were evaluated with the Student's t-test $(* P<0.05)$. Abbreviations: NF- $\kappa B$, nuclear factor kappa B; TNF- $\alpha$, tumor necrosis factor alpha.

changes were not significantly different compared with the control animals. Normal hematological findings and kidney and liver function was demonstrated in the boldine-treated group, indicating this compound did not affect major organ function in vivo (Table 1).

\section{Boldine reduces tumor size in vivo}

To examine the antitumor activity of boldine, female SpragueDawley rats were inoculated with LA7 rat mammary adenocarcinoma cells. Ten days after tumor engraftment, the animals

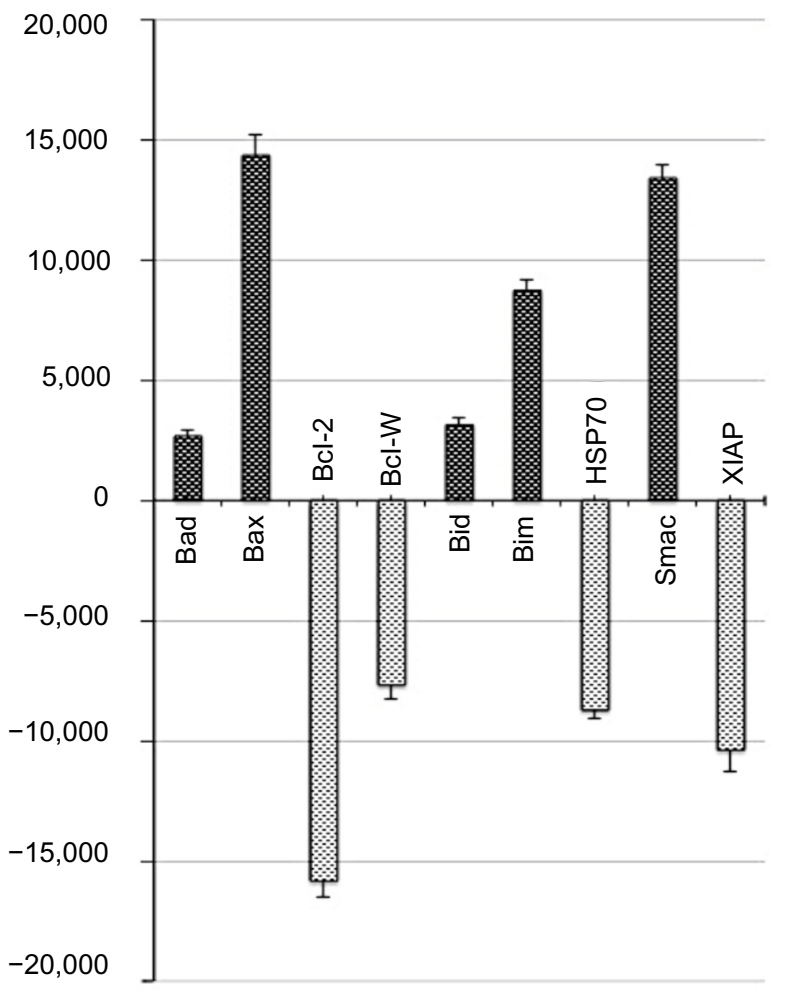

Figure 8 Effect of boldine on expression of apoptosis-related molecules. Human apoptosis proteome profiler array in MDA-MB-23I cells treated with boldine at an $I_{50}$ dose for 24 hours. Graph shows the fold change difference between treated and untreated control cells. The results are represented as the mean \pm standard deviation of three independent experiments.

were either not treated or treated with vehicle $(50 \%$ ethanol/ water), boldine $50 \mathrm{mg} / \mathrm{kg} /$ day, or boldine $100 \mathrm{mg} / \mathrm{kg} /$ day. Fourteen days after treatment ( 24 days after implantation of tumor cells), the tumors were removed for measurement of size. Tumor volume quantification for the experimental groups presented in Figure 10 showed that the animals treated with boldine $(50 \mathrm{mg} / \mathrm{kg} /$ day or $100 \mathrm{mg} / \mathrm{kg} /$ day) had a marked reduction in tumor volume, compared with the control and vehicle groups. However, tumor formation in rats was not significantly inhibited by the lower boldine dose $(25 \mathrm{mg} / \mathrm{kg} /$ day; data not shown). On the other hand, no statistically significant difference was observed between the vehicle and control groups. These results clearly indicate the effectiveness of boldine in reducing breast cancer growth in vivo.

\section{Discussion}

Breast cancer is one of the leading causes of cancer death among women worldwide. Despite the availability of chemotherapeutic regimens, patients with breast cancer undergoing chemotherapy face risks such as drug-related complications and emergence of chemoresistant tumors, which contribute to considerable morbidity and mortality. To overcome this, 

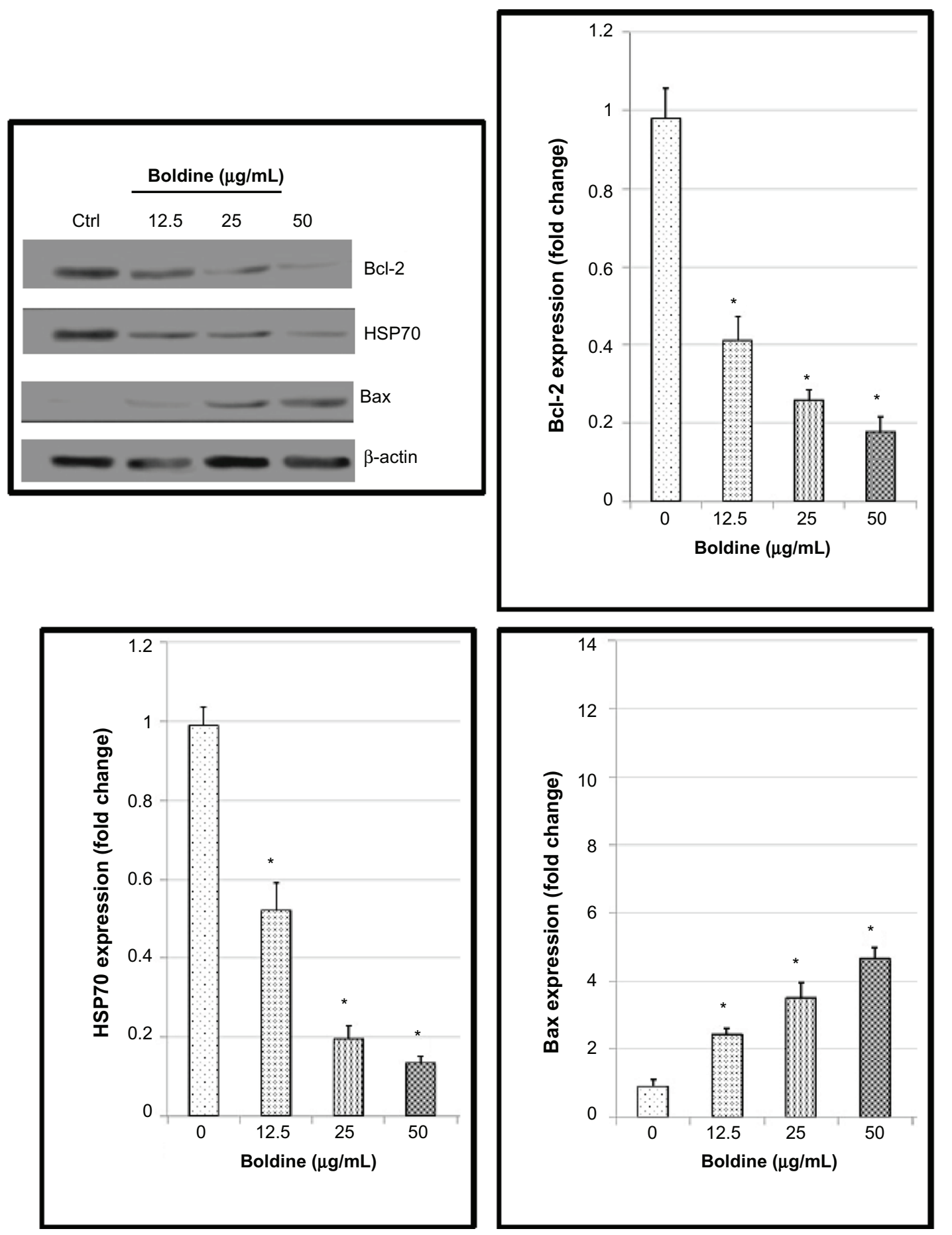

Figure 9 Western blot analysis of boldine-treated MDA-MB-23I cells. Cells were treated with boldine for 24 hours before being lysed and subjected to separation by sodium dodecyl sulfate polyacrylamide gel electrophoresis. Proteins were then transferred to membrane and probed with antibodies against Bax, Bcl-2, and heat shock protein 70 . The membrane was reprobed with anti- $\beta$-actin antibody as the loading control. The band densities of the boldine-treated samples were normalized to the control. Data are shown as the mean \pm standard deviation $(n=3)$. Data were analyzed by the Student's $t$-test $(* P<0.05)$.

scientists and clinicians are turning their attention to plantderived compounds, hoping to find more effective therapeutic agents for breast cancer.

In the present study, boldine was evaluated for its cytotoxic effect in human breast cancer cells using the MTT cell viability assay. The cytotoxic effect of boldine was also confirmed by measuring lactate dehydrogenase release from boldine-treated cells. Elevated lactate dehydrogenase release confirmed the cytotoxic effect of boldine, possibly mediated via activation of an apoptosis or necrosis pathway. ${ }^{23}$ 
Table I Acute toxicity test for boldine in Sprague-Dawley rats. Effects of boldine on (A) kidney function, (B) liver function, and (C) hematological parameters in rats. Boldine and vehicle were administered intraperitoneally to the animals for I4 days. Mortality or any onset of clinical or toxicological symptoms was recorded during the study period. On day I5, blood was drawn from these animals to determine the hematological and serum biochemical parameters according to the OECD.

\begin{tabular}{|c|c|c|c|c|c|c|c|c|c|c|c|}
\hline \multicolumn{12}{|l|}{ A } \\
\hline \multirow{2}{*}{$\begin{array}{l}\text { Animal } \\
\text { groups }\end{array}$} & \multicolumn{11}{|c|}{ Kidney function tests } \\
\hline & \multicolumn{2}{|c|}{$\begin{array}{l}\text { Sodium } \\
(\mathrm{mM} / \mathrm{L})\end{array}$} & $\begin{array}{l}\text { Potassium } \\
(\mathrm{mM} / \mathrm{L})\end{array}$ & \multicolumn{2}{|c|}{$\begin{array}{l}\text { Chloride } \\
(\mathrm{mM} / \mathrm{L})\end{array}$} & \multicolumn{3}{|c|}{$\begin{array}{l}\mathrm{CO}_{2} \\
(\mathrm{mM} / \mathrm{L})\end{array}$} & $\begin{array}{l}\text { Anion } \\
(\mathrm{mM} / \mathrm{L})\end{array}$ & $\begin{array}{l}\text { Urea } \\
(\mathrm{mM} / \mathrm{L})\end{array}$ & $\begin{array}{l}\text { Creatinine } \\
(\mu M / L)\end{array}$ \\
\hline Control & \multicolumn{2}{|c|}{$139.74 \pm 2.07$} & $5.37 \pm 0.37$ & \multicolumn{2}{|c|}{$101.45 \pm 2.11$} & \multicolumn{3}{|c|}{$22.59 \pm 0.18$} & $18.97 \pm 0.28$ & $5.17 \pm 0.13$ & $45.37 \pm 2.01$ \\
\hline $50 \mathrm{mg} / \mathrm{kg} / \mathrm{day}$ & \multicolumn{2}{|c|}{$140.92 \pm 1.68$} & $5.16 \pm 0.52$ & \multicolumn{2}{|c|}{$101.18 \pm 1.35$} & \multicolumn{3}{|c|}{$23.01 \pm 0.37$} & $20.28 \pm 0.4 I$ & $5.02 \pm 0.29$ & $42.6 I \pm 1.29$ \\
\hline $100 \mathrm{mg} / \mathrm{kg} /$ day & \multicolumn{2}{|c|}{$|37.58 \pm 2.2|$} & $5.24 \pm 0.19$ & \multicolumn{2}{|c|}{$99.76 \pm 1.61$} & \multicolumn{3}{|c|}{$20.14 \pm 0.25$} & $19.82 \pm 0.17$ & $4.93 \pm 0.34$ & $41.59 \pm 1.72$ \\
\hline \multicolumn{12}{|l|}{ B } \\
\hline \multirow{2}{*}{$\begin{array}{l}\text { Animal } \\
\text { groups }\end{array}$} & \multicolumn{11}{|c|}{ Liver function tests } \\
\hline & $\begin{array}{l}\text { Total } \\
\text { protein } \\
\text { (g/L) }\end{array}$ & $\begin{array}{l}\text { Albumin } \\
\text { (g/L) }\end{array}$ & $\begin{array}{l}\text { Globulin } \\
\text { (g/L) }\end{array}$ & $\begin{array}{l}\text { Total } \\
\text { bilirubin } \\
(\mu \mathrm{M} / L)\end{array}$ & \multicolumn{2}{|c|}{$\begin{array}{l}\text { Conjugated } \\
\text { bilirubin } \\
(\mu \mathrm{M} / L)\end{array}$} & $\begin{array}{l}\text { All } \\
\text { ph } \\
\text { (IU }\end{array}$ & $\begin{array}{l}\text { kaline } \\
\text { osphatase } \\
\text { J/L) }\end{array}$ & $\begin{array}{l}\text { Alanine } \\
\text { transaminase } \\
(I U / L)\end{array}$ & $\begin{array}{l}\text { Aspartate } \\
\text { transaminase } \\
\text { (IU/L) }\end{array}$ & $\begin{array}{l}\text { GGT } \\
\text { (IU/L) }\end{array}$ \\
\hline Control & $72.15 \pm 1.28$ & $12.62 \pm 0.24$ & $58.42 \pm 1.04$ & $2.21 \pm 0.13$ & 0.94 & \pm 0.23 & & $6.12 \pm 3.18$ & $52.7 I \pm 1.63$ & $156.34 \pm 3.78$ & $4.82 \pm 0.18$ \\
\hline $50 \mathrm{mg} / \mathrm{kg} /$ day & $71.38 \pm 1.54$ & $12.17 \pm 0.32$ & $57.91 \pm 0.83$ & $2.09 \pm 0.08$ & 0.87 & \pm 0.17 & & $7.25 \pm 1.54$ & $52.49 \pm 2.44$ & $|54.9| \pm 3.24$ & $4.26 \pm 0.25$ \\
\hline $100 \mathrm{mg} / \mathrm{kg} / \mathrm{day}$ & $70.46 \pm 1.03$ & $12.35 \pm 0.18$ & $59.13 \pm 1.17$ & $1.98 \pm 0.11$ & 0.91 & \pm 0.14 & & $6.01 \pm 2.78$ & $53.27 \pm 2.06$ & $155.48 \pm 1.96$ & $4.73 \pm 0.22$ \\
\hline C & & & & & & & & & & & \\
\hline Animal & Hematolo & gical analys & & & & & & & & & \\
\hline groups & HGB & HCT & RBC & MCV & & МСH & & МСHC & RDW & WBC & Platelet \\
\hline Control & $157.24 \pm 3.14$ & $0.64 \pm 0.0$ & $8.73 \pm 0.35$ & $64.7 I \pm I$ & & $18.23 \pm 0$ & & $307.56 \pm 4.8$ & $17.43 \pm 0.94$ & $8.61 \pm 1.14$ & $862.94 \pm 27.45$ \\
\hline $50 \mathrm{mg} / \mathrm{kg} / \mathrm{day}$ & $|55.6| \pm 2.75$ & $0.61 \pm 0.0$ & $8.89 \pm 0.26$ & $65.19 \pm 1$ & & $17.95 \pm 0$ & & $329.34 \pm 5.12$ & $18.79 \pm 1.03$ & $9.16 \pm 0.96$ & $881.35 \pm 34.92$ \\
\hline 100 mg/kg/day & $154.94 \pm 2.88$ & $0.63 \pm 0.0$ & $9.01 \pm 0.31$ & $65.82 \pm 1$ & & $|8.4| \pm 0$ & & $319.67 \pm 3.86$ & $19.11 \pm 0.82$ & $8.93 \pm 1.05$ & $913.58 \pm 29.65$ \\
\hline
\end{tabular}

Notes: (A) Values are expressed as the mean \pm standard deviation. There are no significant differences between groups. (B) Values expressed as the mean \pm standard deviation. There are no significant differences between groups. (C) Values are expressed as the mean \pm standard deviation. There are no significant differences between groups.

Abbreviations: GGT, gamma glutamyl transferase; HGB, hemoglobin; HCT, hematocrit; RBC, red cell count; MCV, mean corpuscular volume; MCH, mean corpuscular hemoglobin; MCHC, mean corpuscular hemoglobin concentration; RDW, red cell distribution width; WBC, white blood cells; OECD, Organization for Economic Cooperation and Development.

Apoptosis and necrosis can be differentiated by observation of cell morphology, whereby necrotic cells swell and apoptotic cells shrink in size. In addition, DNA from necrotic cells will form a smear whereas DNA from apoptotic cells show distinctive DNA fragments with a laddering pattern under gel electrophoresis. ${ }^{24}$ In our study, we observed both cellular shrinkage and DNA fragmentation, supporting the observation that treatment with boldine leads to apoptosis rather than necrosis in MDA-MB-231 breast cancer cells.

Cell cycle check points are control mechanisms that ensure proper timing of cell division and the integrity of DNA. In the event of DNA damage, entry into mitosis is blocked by a $\mathrm{G} 2 / \mathrm{M}$ checkpoint mechanism to allow initiation of the cell repair mechanism. ${ }^{25}$ If the damage is severe or beyond repair, cells will undergo apoptosis. Using flow cytometry analysis, we showed that boldine dose-dependently induced G2/M cell cycle arrest, correlating with increased DNA damage as observed in the DNA fragmentation assay. G2/M cell cycle regulation involves multiple molecules, including ataxia telangiectasia mutated-related kinase, checkpoint kinases CHK1 and CHK2, p53, CDC25 phosphatases, and p21 $1^{\text {wafl/cip1 }}$ cyclin-dependent kinase inhibitor. ${ }^{26-30}$ Although we demonstrated that boldine could induce cell cycle arrest and apoptosis, the effect of boldine on these G2/M check point regulatory proteins and the precise cell cycle arrest mechanism involved remains to be elucidated.

The intrinsic or mitochondrial-dependent signaling pathway involves different factors of non-receptor-mediated stimuli that induce intracellular signals. Collapse of MMP indicates depolarization of the mitochondrial membrane, causing translocation of cytochrome c from the mitochondrial matrix to the cytosol. Release of cytochrome $\mathrm{c}$ then triggers activation of downstream caspase molecules, leading to apoptotic cell death. Binding of cytochrome $\mathrm{c}$ to apoptotic activating factor-1, caspase- 9 is activated via apoptosome formation can lead to activation of caspase-3/7, the most effective caspase, with many cellular targets such as poly-ADP ribose polymerase, ICAD/ 


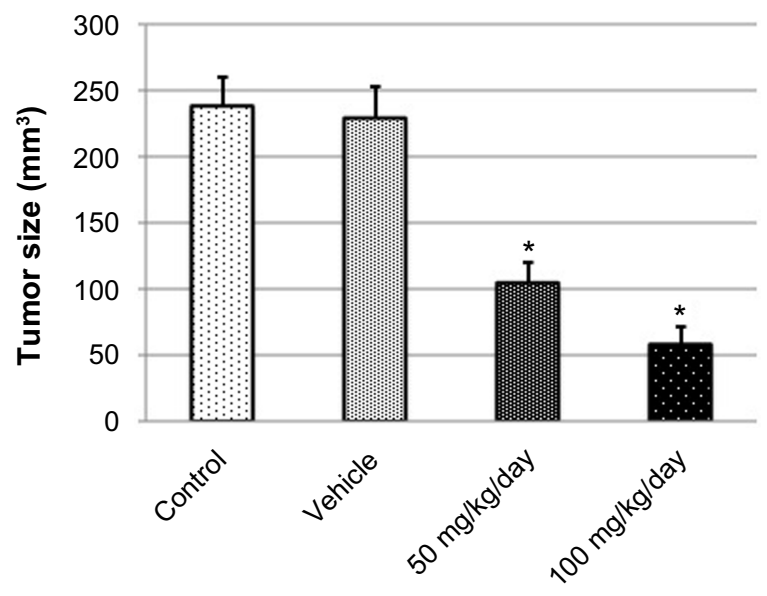

Figure 10 Boldine suppresses tumor formation in vivo. Tumor size quantification of implanted mammary carcinoma LA7. The values are shown as the mean \pm standard deviation (control group, five animals; vehicle group, five animals; boldine-treated group (50 mg/kg/day), five animals; boldine-treated group (100 mg/kg/day), five animals). The data were analyzed by Student's $t$-test $(* P<0.05)$.

DFF45 (inhibitor of caspase-activated DNase). ${ }^{31-33}$ On the other hand, the extrinsic apoptotic pathway is mediated by death receptors. For example, FAS ligand interacts with the FAS receptor, leading to activation of caspase- 8 and downstream executioner caspases. ${ }^{34-36}$ In this study, we observed that treatment with boldine resulted in significant elevation of caspase-9 activity compared with the control. Meanwhile, there was no activation of caspase- 8 , suggesting that induction of apoptosis by boldine in MDA-MB-231 cells is mediated via the intrinsic mitochondrial caspase-9 pathway. ${ }^{37-39}$

The release of cytochrome $c$ is strictly regulated by the Bcl-2 family proteins. The proapoptotic Bcl-2 family protein, Bax, disrupts the MMP and causes release of cytochrome c. Meanwhile, antiapoptotic Bcl-2 family members, ie, Bcl-2 and Bcl-xl, keep Bax in its inactive form. ${ }^{40,41}$ In our study, treatment with boldine dose-dependently downregulated the expression of Bcl-2 and simultaneously enhanced the expression of Bax. The downregulation of Bcl-2 could be attributed to blockage of NF- $\kappa B$ activation, because another study showed that inhibition of NF- $\mathrm{KB}$ downregulated Bcl-2 expression in chronic lymphocytic leukemia. ${ }^{42}$ Another antiapoptotic protein, HSP70, is highly expressed in breast cancer cells. HSP70 induces resistance against apoptosis, thus enhances the survival of cancer cells. ${ }^{43,44}$ We showed that boldine suppressed HSP70 in a dose-dependent manner, which further supports its apoptosis-inducing properties.

Next, we tested the acute toxicity of boldine in SpragueDawley rats, where no signs of toxicity and mortality were observed over a period of 14 days, indicating the safety of boldine. Neither hepatic toxicity nor renal toxicity was detected in the biochemistry-based function tests. We also evaluated the effect of boldine on tumor growth in SpragueDawley rats implanted with LA7 breast adenocarcinoma for a duration of 14 days. The boldine-treated groups $(50 \mathrm{mg} / \mathrm{kg} /$ day and $100 \mathrm{mg} / \mathrm{kg} /$ day) showed significant tumor size reduction compared with the control and vehicle groups, indicating the potential chemotherapeutic value of boldine in vivo. Of note, boldine has been used to treat minor biliary dysfunction and as an adjuvant in constipation. The daily oral dose of boldine in humans is around $10-50 \mathrm{mg}$ /day or $2-5 \mathrm{~g}$ of the drug as a tea infusion. ${ }^{45}$ Future clinical studies regarding the tolerated dose and pharmacokinetics are needed in humans in order to develop boldine further as an anticancer agent.

In conclusion, this study demonstrates the cytotoxic effect of boldine and its potent therapeutic effect in breast cancer using in vitro and in vivo models. Further investigations of this compound may pave the way for development of boldine as a potential anticancer agent.

\section{Acknowledgments}

The authors thank Professor Ian C Paterson (University of Malaya) for providing research materials, and Alicia Yiling Phan (University of Malaya) for technical assistance. The present study was financially supported by a University of Malaya research grant (UMRG 045/11BIO), a postgraduate research grant from the University of Malaya (PS366/2010B), and a High Impact research grant from the University of Malaya (E00002-20001).

\section{Disclosure}

The authors report no conflicts of interest in this work.

\section{References}

1. Atawodi SE. Nigerian foodstuffs with prostate cancer chemopreventive polyphenols. Infect Agent Cancer. 2011;6:S9.

2. Jemal A, Siegel R, Ward E, Murray T, Xu J, et al. Cancer statistics, 2007. CA Cancer J Clin. 2007;57:43-66.

3. Garcia M, Jemal A, Ward EM, et al. Global Cancer Facts and Figures 2007. American Cancer Society. 2007. Available from: https:// www.cancer.org/acs/groups/content/@nho/documents/document/ globalfactsandfigures2007rev2p.pdf. Accessed March 18, 2014.

4. Berry DA, Cronin KA, Plevritis SK, et al. Effect of screening and adjuvant therapy on mortality from breast cancer. $N$ Engl J Med. 2005;353: 1784-1792.

5. Ravdin PM, Cronin KA, Howlader N, et al. The decrease in breastcancer incidence in 2003 in the United States. N Engl J Med. 2007;356: 1670-1674.

6. Jemal A, Siegel R, Xu J, et al. Cancer statistics, 2010. CA Cancer J Clin. 2010;60:277-300. 
7. Patel MR, Dehmer GJ, Hirshfeld JW, Smith PK, Spertus JA. ACCF/ SCAI/STS/AATS/AHA/ASNC 2009. Appropriateness Criteria for Coronary Revascularization. A Report by the American College of Cardiology Foundation Appropriateness Criteria Task Force, Society for Cardiovascular Angiography and Interventions, Society of Thoracic Surgeons, American Association for Thoracic Surgery, American Heart Association, and the American Society of Nuclear Cardiology Endorsed by the American Society of Echocardiography, the Heart Failure Society of America, and the Society of Cardiovascular Computed Tomography. J Am Coll Cardiology. 2009;53:530-553.

8. Scatena R. Mitochondria and cancer: a growing role in apoptosis, cancer cell metabolism and dedifferentiation. In: Advances in Mitochondrial Medicine. New York, NY, USA: Springer; 2012.

9. Verfaillie T, Garg AD, Agostinis P. Targeting ER stress induced apoptosis and inflammation in cancer. Cancer Lett. 2013;332:249-264.

10. Lee MJ, Ye AS, Gardino AK, et al. Sequential application of anticancer drugs enhances cell death by rewiring apoptotic signaling networks. Cell. 2012;149:780-794.

11. Chakraborty A, Kumar P, Ghosh K, Roy P. Evaluation of a Schiff base copper complex compound as potent anticancer molecule with multiple targets of action. Eur J Pharmacol. 2010;647:1-12.

12. Rey NA, Neves A, Silva PP, et al. A synthetic dinuclear copper (II) hydrolase and its potential as antitumoral: cytotoxicity, cellular uptake, and DNA cleavage. J Inorg Biochem. 2009;103:1323-1330.

13. Suzuki R, Yasui Y, Kohno H, et al. Catalpa seed oil rich in 9t, 11t, 13c-conjugated linolenic acid suppresses the development of colonic aberrant crypt foci induced by azoxymethane in rats. Oncol Rep. 2006;16:989-996.

14. Speisky H, Cassels BK. Boldo and boldine: an emerging case of natural drug development. Pharmacol Res. 1994;29:1-12.

15. Morello A, Lipchenka I, Cassels BK, Speisky H, Aldunate J, Repetto Y. Trypanocidal effect of boldine and related alkaloids upon several strains of Trypanosoma cruzi. Comp Biochem Physiol Pharmacol Toxicol Endocrinol. 1994;107:367-371.

16. Jiménez I, Speisky H. Biological disposition of boldine: in vitro and in vivo studies. Phytother Res. 2000;14:254-260.

17. Backhouse N, Delporte C, Givernau M, et al. Anti-inflammatory and antipyretic effects of boldine. Agents Actions. 1994;42:114-117.

18. Gerhardt D, Horn AP, Gaelzer MM, et al. Boldine: a potential new antiproliferative drug against glioma cell lines. Invest New Drugs. 2009;27:517-525.

19. Gerhardt D, Bertola G, Dietrich F, et al. Boldine induces cell cycle arrest and apoptosis in T24 human bladder cancer cell line via regulation of ERK, AKT AND GSK-3ß. Urol Oncol. 2014;32:36. e1-e9.

20. Gummadi VR, Rajagopalan S, Looi CY, et al. Discovery of 7-azaindole based anaplastic lymphoma kinase (ALK) inhibitors: wild type and mutant (L1196M) active compounds with unique binding mode. Bioorg Med Chem Lett. 2013;23:4911-4918.

21. Looi CY, Imanishi M, Takaki S, et al. Octa-arginine mediated delivery of wild-type Lnk protein inhibits TPO-induced M-MOK megakaryoblastic leukemic cell growth by promoting apoptosis. PLoS One. 2011;6:e23640.

22. Looi CY, Moharram B, Paydar M, et al. Induction of apoptosis in melanoma A375 cells by a chloroform fraction of Centratherum anthelminticum (L.) seeds involves NF-kappaB, p53 and Bcl-2-controlled mitochondrial signaling pathways. BMC Complement Altern Med. 2013;13:166.

23. Choi EJ, Lee JI, Kim G-H. Evaluation of the anticancer activities of thioflavanone and thioflavone in human breast cancer cell lines. Int $J$ Mol Med. 2012;29:252-256.

24. Collins JA, Schandl CA, Young KK, Vesely J, Willingham MC. Major DNA fragmentation is a late event in apoptosis. J Histochem Cytochem. 1997;45:923-934.

25. Hartwell LH, Weinert TA. Checkpoints: controls that ensure the order of cell cycle events. Science. 1989;246:629-634.
26. Kastan MB, Bartek J. Cell-cycle checkpoints and cancer. Nature. 2004;432:316-323.

27. Abraham RT. Cell cycle checkpoint signaling through the ATM and ATR kinases.Genes Dev. 2001;15:2177-2196.

28. Zhou BB, Elledge SJ. The DNA damage response: putting checkpoints in perspective. Nature. 2000;408:433-439.

29. Meyers M, Hwang A, Wagner MW, Boothman DA. Role of DNA mismatch repair in apoptotic responses to therapeutic agents. Environ Mol Mutagen. 2004;44:249-264.

30. De Siervi A, Marinissen M, Diggs J, Wang XF, Pages G, Senderowicz A. Transcriptional activation of $\mathrm{p} 21^{\text {wafl/cipl } 1}$ by alkylphospholipids: role of the mitogen-activated protein kinase pathway in the transactivation of the human p21 waf1/cipl promoter by Sp1. Cancer Res. 2004;64: 743-750.

31. Li LY, Luo X, Wang X. Endonuclease G is an apoptotic DNase when released from mitochondria. Nature. 2001;412:95-99.

32. Tang D, Kidd VJ. Cleavage of DFF-45/ICAD by multiple caspases is essential for its function during apoptosis. $J$ Biol Chem. 1998;273:28549-28552.

33. Boucher D, Blais V, Denault JB. Caspase-7 uses an exosite to promote poly(ADP ribose) polymerase 1 proteolysis. Proc Natl Acad Sci U SA. 2012;109:5669-5674.

34. El-Ghany RM, Sharaf NM, Kassem LA, Mahran LG, Heikal OA. Thymoquinone triggers anti-apoptotic signaling targeting death ligand and apoptotic regulators in a model of hepatic ischemia reperfusion injury. Drug Discov Ther. 2009;3:296-306.

35. Hyer ML, Shi R, Krajewska M, et al. Apoptotic activity and mechanism of 2-cyano-3, 12-dioxoolean-1, 9-dien-28-oic-acid and related synthetic triterpenoids in prostate cancer. Cancer Res. 2008;68:2927-2933.

36. Qi F, Li A, Inagaki Y, et al. Induction of apoptosis by cinobufacini preparation through mitochondria-and Fas-mediated caspase-dependent pathways in human hepatocellular carcinoma cells. Food Chem Toxicol. 2012;50:295-302.

37. Soengas MS, Alarcon RM, Yoshida H, et al. Apaf-1 and caspase-9 in p53-dependent apoptosis and tumor inhibition. Science. 1999;284: $156-159$.

38. Cui H, Schroering A, Ding HF. p53 mediates DNA damaging druginduced apoptosis through a caspase-9-dependent pathway in SH-SY5Y neuroblastoma cells. Mol Cancer Ther. 2002;1:679-686.

39. Wu GS, Ding Z. Caspase 9 is required for p53-dependent apoptosis and chemosensitivity in a human ovarian cancer cell line. Oncogene. 2002;21:1-8.

40. Szegezdi E, Logue SE, Gorman AM, Samali A. Mediators of endoplasmic reticulum stress-induced apoptosis. EMBO Rep. 2006;7:880-885.

41. Vogler M, Hamali HA, Sun XM, et al. BCL2/BCL-XL inhibition induces apoptosis, disrupts cellular calcium homeostasis, and prevents platelet activation. Blood. 2011;117:7145-7154.

42. Tracey L, Pérez-Rosado A, Artiga MJ, et al. Expression of the NF-kappaB targets BCL2 and BIRC5/Survivin characterizes small B-cell and aggressive B-cell lymphomas, respectively. J Pathol. 2005;206:123-134.

43. Mayer MP, Bukau B. Hsp70 chaperones: cellular functions and molecular mechanism. Cell Mol Life Sci. 2005;62:670-684.

44. Nylandsted J, Rohde M, Brand K, Bastholm L, Elling F, Jäättelä M. Selective depletion of heat shock protein 70 (Hsp 70) activates a tumorspecific death program that is independent of caspases and bypasses Bcl-2. Proc Natl Acad Sci U S A. 2000;97:7871-7876.

45. The European Agency for the Evaluation of Medicinal Products [webpage on the Internet]. Committee for Veterinary Medicinal Products. Summary Report. 1999. Available from: http://www.ema.europa. eu/docs/en_GB/document_library/Maximum_Residue_Limits_-Report/2009/11/WC500011107.pdf. Accessed April 25, 2014. 
Drug Design, Development and Therapy

Dovepress

\section{Publish your work in this journal}

Drug Design, Development and Therapy is an international, peerreviewed open-access journal that spans the spectrum of drug design and development through to clinical applications. Clinical outcomes, patient safety, and programs for the development and effective, safe, and sustained use of medicines are a feature of the journal, which

has also been accepted for indexing on PubMed Central. The manuscript management system is completely online and includes a very quick and fair peer-review system, which is all easy to use. Visit http://www.dovepress.com/testimonials.php to read real quotes from published authors.

Submit your manuscript here: http://www.dovepress.com/drug-design-development-and-therapy-journal 